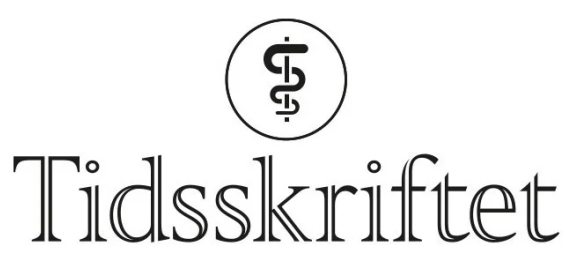

DEN NORSKE LEGEFORENING

\title{
Med ordet i sin makt, men ikke i sin orden
}

\author{
ANMELDELSER
}

\section{MAGNE NYLENNA}

Professor i samfunnsmedisin og ordbokredaktør, Institutt for helse og samfunn Universitetet i Oslo

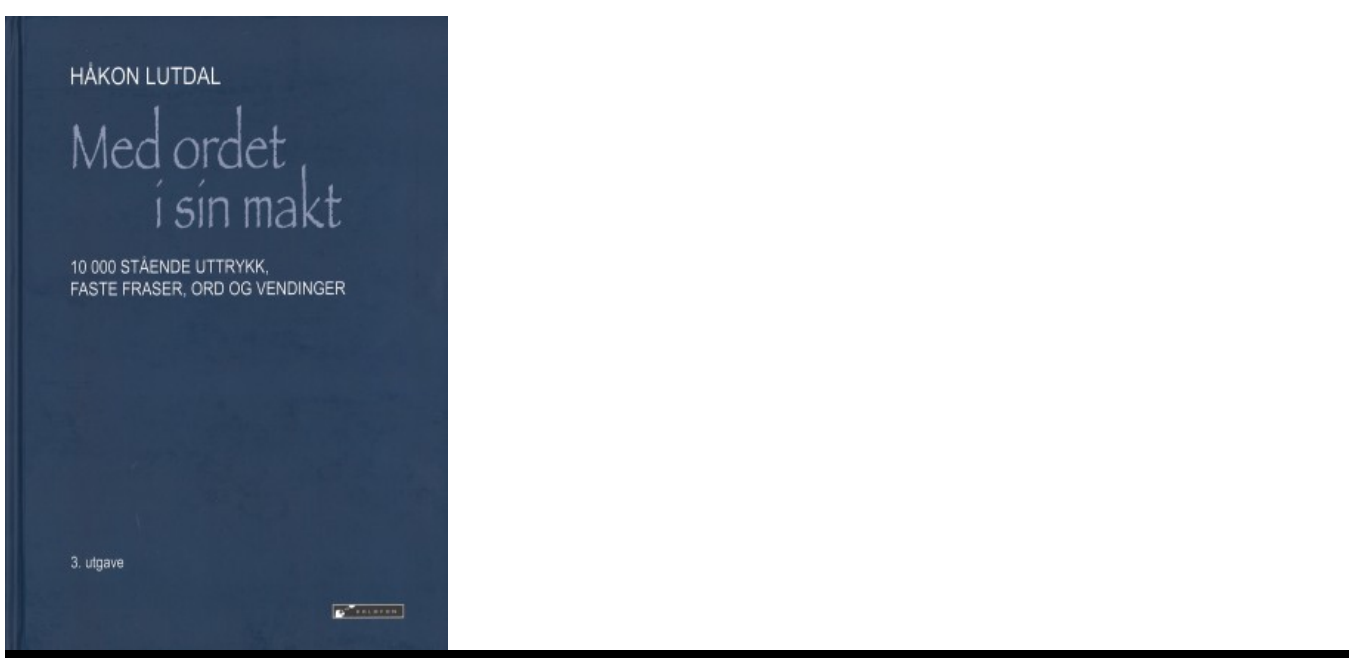

Håkon Lutdal

Med ordet i sin makt

10 ooo stående uttrykk, faste fraser, ord og vendinger. 3. utg. 648 s. Oslo: Kolofon, 2019. Pris NOK 375

ISBN 978-82-300-1498-1

Jeg beundrer entusiaster. Og uten å kjenne forfatteren av denne boken, fornemmer jeg et eksemplar av arten. Samler er Håkon Lutdal i hvert fall helt sikkert, og hensikten med denne boken beskriver han som «å samle flest mulig faste uttrykk, ord og vendinger som brukes i billedlig eller overført betydning». Fangsten har blitt 10 ooo «bidrag til å holde språksegmentet levende». Det inkluderer mye å både humre og gruble over. 
Språket er vårt viktigste verktøy i kommunikasjon med andre mennesker, enten det skjer skriftlig eller muntlig, overfor pasienter eller kolleger. Presset mot norsk språk er økende. Først og fremst gjelder det fagspråket, som trues av engelske ord og termer. Men også allmennspråket påvirkes av et kulturelt og etnisk mangfold som reduserer antall felles språklige referanser og gjør bruken av metaforer og idiomer vanskeligere. Når pasienten "går på veggen» eller "sover som en stein», må det selvsagt forstås på bakgrunn av formuleringenes overførte betydning, noe som forutsetter språklig kompetanse.

«Å lære en kulturs idiomer og andre faste uttrykk er å dyppe seg selv ned i den kulturen», skriver forfatteren i forordet. Språkinteresserte norske menn og kvinner vil neppe finne mange overraskelser i forklaringene av de mange ordene og uttrykkene i denne boken. Men er man ukjent med norsk språk og kultur, kan det sikkert være mye å lære.

Hovedproblemet med boken er redigeringen. Når noen ord og uttrykk alfabetiseres ut fra sin ubestemte artikkel, blir det for eksempel 125 sider med «en» og «et» som oppslagsord, fra «en ablegøye» til «et åndsverk». Det er ikke særlig brukervennlig om man leter etter betydningen av et bestemt ord. Jeg foretrekker språkprofessor Kjell Ivar Vannebos organisering av tilsvarende uttrykk i boken Prikken over i-en og andre uttrykk (Cappelen Damm, 2011). Vannebo alfabetiserer med utgangspunkt i det første substantivet som inngår i uttrykket. I Norsk etymologisk ordbok (Kagge forlag, 2013) løser Yann de Caprona gjenfinningsproblemet med et omfattende alfabetisk register over enkeltord bakerst i boken. Kanskje en ide til 4. utgave av denne boken også?

Publisert: 4. mai 2020. Tidsskr Nor Legeforen. DOI:10.4045/tidsskr.20.0152

(C) Tidsskrift for Den norske legeforening 2023. Lastet ned fra tidsskriftet.no 26. april 2023. 